
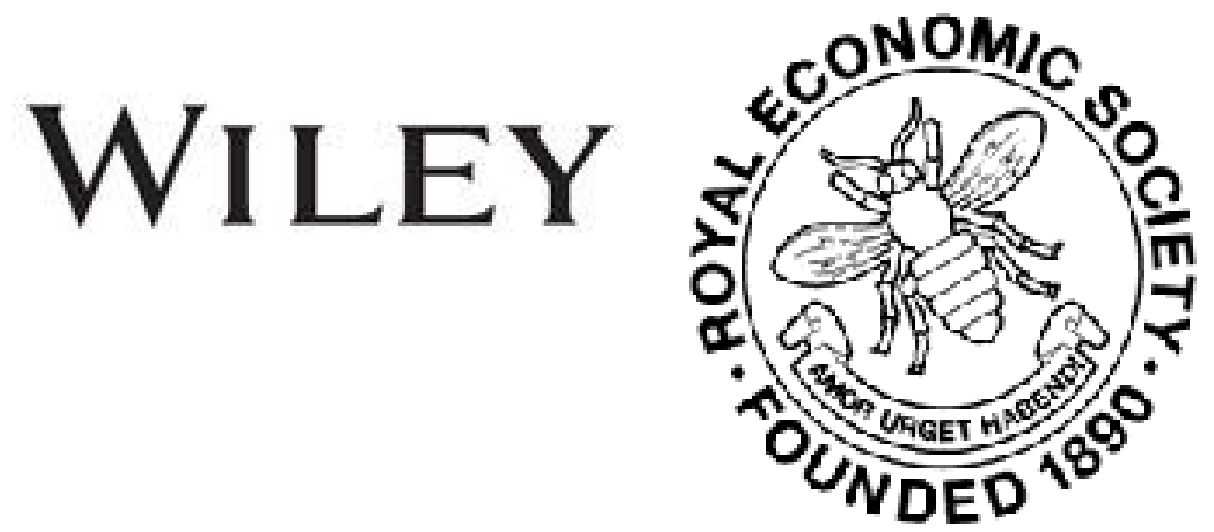

The Railway Rates Committee

Author(s): John Macdonell

Source: The Economic Journal, Vol. 1, No. 2 (Jun., 1891), pp. 396-397

Published by: Wiley on behalf of the Royal Economic Society

Stable URL: http://www.jstor.org/stable/2956259

Accessed: 27-06-2016 03:27 UTC

Your use of the JSTOR archive indicates your acceptance of the Terms \& Conditions of Use, available at

http://about.jstor.org/terms

JSTOR is a not-for-profit service that helps scholars, researchers, and students discover, use, and build upon a wide range of content in a trusted digital archive. We use information technology and tools to increase productivity and facilitate new forms of scholarship. For more information about JSTOR, please contact support@jstor.org.

Wiley, Royal Economic Society are collaborating with JSTOR to digitize, preserve and extend access to The Economic Journal 
lishments had abandoned Portugal, they would not rest until Portuguese 3 per cents. which were over 60 not very long ago, had dropped to 15. Having been used to leaning on foreign loans, the Government of Portugal cannot walk without its accustomed crutches. It seems to be worth the while of the French banks and others to advance money for the payment of some Portuguese coupons, meanwhile 'unloading' their stock on the markets. If not, Portugal must make a composition. Unluckily, Spain found her creditors so ready to accept (say) $10 s$. in the pound that Portugal is too likely to propose similar terms.

ARthur ElLis

\section{The Railway Rates Committee}

THE preparation of the new statutory classification and schedule of maximum rates and charges of railway companies still goes on before the Joint Parliamentary Committee of which the Duke of Richmond is chairman. A few facts and figures will show the magnitude of the task and the slow pace at which it is being performed. The Railway and Canal Traffic Act giving power to alter the charging powers of 976 railway companies under some 900 Acts was passed in August 1888 ; time for the companies to send in their proposed classifications and schedules was extended to June 1889 ; an inquiry into the proposals and the objections of the traders by Lord Balfour of Burleigh and Mr. Courtenay Boyle began October 1889, lasting for several months, and ending in a report declaring in favour of basing the new maxima, not on the old statutory maxima, but on the actual rates. This inquiry satisfied no one. The traders presented alarming calculations founded on a comparison of the present rates with the new maxima. The Lancashire and Cheshire Conference, which has fought the battle of the traders, pressed for further reductions. The opinions of the Railway Companies were expressed in the complaint to the Board of Trade of the London and North Western Railway: 'The adoption of figures such as those proposed would diminish the present annual revenue of the Company by so large a sum as to render it quite impossible for the directors to submit to the proposal, except under the compulsion of Parliament. Apart, however, from the precise result of the figures there seems to have been in the settlement of the proposed rates a total departure from the principle upon which railway shareholders have hitherto understood that the revision of the existing statutory powers was to be conducted.' Then came negotiations, resulting in changes chiefly in favour of the traders, and a further inquiry by a Joint Committee of both Houses of Parliament into the Bills embodying the Provisional Orders of the Board of Trade-an inquiry which threatens to equal in length that conducted at the instance of the Board of Trade. The longer the investigation lasts the wider becomes the impression that the endeavour to find 'just and reasonable' maxima for thousands of articles of commerce of course must be futile labour. 
The Committee have made many changes in the classification of individual articles; but the chief alteration in the Board of Trade proposals relates to terminal charges. There are three possible modes of dealing with them : authorize railway companies to charge reasonable sums for terminal services; fix an individual maximum for station and service terminals at every station in the United Kingdom; fix a uniform maximum, based on a fair average. Lord Balfour of Burleigh and Mr. Courtenay Boyle preferred the third solution, not as perfect, but as open to fewer objections than the two other modes. The Joint Committee have decided that the companies may charge a reasonable sum within a certain maximum, to be determined in case of dispute by arbitrators-which means in practice the first method. In other words, a reasonable sum, having regard to the services and the nature of the stations, may be charged. The customers of the companies are likely to regard this solution, with the outlook of litigation which it presents, as a sorry ending to their agitation for the last ten years against terminal charges of any kind.

John MacdonelL

\section{The International Miners' Congress}

THE International Miners' Congress held during the month of April at Paris arose out of the Congress that met at Jolimont in Belgium last year. Ninety-nine delegates were present, representing, it was claimed, 909,167 members, but, as the membership of Continental unions is a matter of estimation rather than of accurate figures, the above total number of miners represented by delegates must be accepted with some degree of reserve. Great Britain sent 41 delegates. Mr. Thomas Burt, M.P., in his opening address as President dwelt strongly on the necessity of union amongst miners, and pointed out that without self-control, moderation, and wise counsel International Federation was impossible.

The burning question for the Congress to decide was the method of voting. The English representatives contended that the votes of the delegates should have weight in proportion to the number of members the delegates of each country represented. The Continental delegates urged that the voting on any question should be by 'nationalities.' In voting by 'nationalities' the majority of delegates from each state decides by show of hands how that state is to vote and then each state gives one vote in accordance with this decision. The result is that the smallest state has the same voting power as the largest. The question was something more than one of mere procedure. The Congress had for its principal object the discussion of a proposal for a universal strike, and the British delegates feared that if the vote was taken by nationalities, the delegates of the smaller states, who represented a comparatively small number of miners by no means thoroughly organized, might drag the miners in other states into a policy they could not approve. Eventually it was agreed to postpone the final settlement of the question.

The resolution in favour of a universal strike before the 1st May was proposed by the Belgians. To the surprise of the British delegates it was found that the greatest possible difference of opinion existed on the subject. M. Basly and Herr Schröder opposed it from the point of view of the French and German miners respectively. The suggestion 